\title{
PENERAPAN MODEL PEMBELAJARAN JIGSAW UNTUK MENINGKATKAN KEAKTIFAN BELAJAR SISWA
}

\section{THE APPLICATION OF MODEL LEARNING JIGSAW TO INCREASE LIVELINESS LEARN OF STUDENT}

\author{
Annisa Fathin Dianah, Moch. Habibi AP, Muh. Afif Nurwan, \\ M. Ali Sofyan \& Lucky Indrawati \\ Universitas Negeri Malang, Indonesia \\ E-mail: annisafathindianah@gmail.com
}

\begin{abstract}
ABSTRAK
Penelitian ini bertujuan untuk Untuk mengetahui bagaimana proses penerapan metode jigsaw di kelas XII J 5 SMA Negeri 9 Malang, dan untuk mengetahui bagaimana hasil penerapan model pembelajaran Jigsaw terhadap keaktifan belajar siswa kelas XII J 5 IPS SMA Negeri 9 Malang. Metode penelitian yang digunakan dalam penelitian ini adalah Penelitian Tindakan Kelas dengan menggunakan pendekatan Lesson study. Teknik pengolahan data dalam penelitian ini menggunakan metode observasi langsung, mendokumentasikan segala macam subjek maupun objek tertentu, dan penggunaan kamera sebagai alat dokumentasi. Selain itu kami juga menggunakan teknik wawancara secara langsung kepada guru pamong, mahasiswa PPL, dan murid-murid peserta LS. Hasil yang didapat dalam penelitian ini dapat menunjukkan bahwa implementasi Strategi Pembelajaran Kooperatif Teknik Jigsaw dapat meningkatkan Keaktifan Belajar Sosiologi Kelas XII J 5 SMA Negeri 9 Malang tahun ajaran 2017/2018. Dengan penggunaan berbagai teknik dalam strategi pembelajaran kooperatif, diantaranya teknik pembelajaran Jigsaw, siswa dapat memusatkan perhatian kepada pembelajaran, sehingga pemahaman siswa terhadap materi pembelajaran dapat ditingkatkan, juga dapat membelajarkan keterampilan sosial. Hal tersebut tampak dari adanya kerja sama antar siswa dalam teknik pembelajaran Jigsaw sebagai upaya untuk memahami konsep dalam materi pelajaran. Dengan adanya kerjasama tersebut, akan melatih keterampilan siswa dalam hal bersosialisasi dengan teman sebaya dan juga akan berpengaruh terhadap meningkatnya keaktifan belajar siswa.
\end{abstract}

Kata Kunci: Pendidikan, Keaktifan, lesson study

\section{ABSTRACT}

This research aims to to know how to process the application of the method of jigsaw in class XII, J9 5 SMA Negeri Malang, and to find out how the results of the application of the learning model Jigsaw against the class XII students learning the liveliness of J 5 IPS SMA Negeri 9 Malang. Research methods used in this research is the Research Action Class by using the approach to Lesson study. Data processing technique in this study using the method of direct observations, documenting all kinds of subjects or certain objects, and the use of the camera as a tool documentation. In addition, we also use interview techniques directly to the teacher of teachers, students, and PPL students' participants LS. The results obtained in this study may indicate that the implementation of Cooperative Learning Strategies can increase the liveliness of the Jigsaw Technique study sociology Class XII J 5 SMA Negeri Malang 2017/2018 school year 9. With the use of various techniques in cooperative learning strategies, learning techniques including Jigsaw, students can focus attention to learning, so that students ' understanding of the learning to the materials can be improved, it can also membelajarkan social skills. It seems from the existence of a partnership between students in the Jigsaw learning techniques in an effort to understand the concept in the subject matter. The existence of such cooperation, will train the student's skills in terms of socializing with peers and will also have an effect on increasing students 'learning activeness.

Keywords: education, liveliness, lesson study

\section{PENDAHULUAN}

Dalam pasal 1 UU RI nomor 14 tahun 2005 tentang guru dan dosen dijelaskan bahwa Guru adalah pendidik profesional dengan tugas utama mendidik, mengajar, membimbing, mengarahkan, melatih, menilai, mengevaluasi peserta didik pada pendidikan anak usia dini jalur pendidikan formal, pendidikan dasar, dan pendidikan menengah. Sedangkan dalam Permendikbud UU No. 57 Tahun 2014 
dijelaskan bahwa kurikulum 2013 bertujuan untuk mempersiapkan manusia indonesia agar memiliki kemampuan hidup sebagai pribadi dan warga negara yang beriman, produktif, kreatif, inovatif, dan afektif serta mampu berkontribusi pada kehidupan bermasyarakat beebangsa dan bernegara dan peradaban dunia.

Akan tetapi faktanya sebagian guru sekarang hanya memberikan tugas ke siswa tanpa memberikan penjelasan yang mendalam. Kebanyakan guru saat ini cenderung sibuk dengan urusan-urusan yang lain dan mengesampingkan tugas utamanya menjadi seorang guru. Siswa hanya diberikan materi dan tugas yang belum tentu siswa dapat pahami. Hal serupa juga terjadi di SMAN 9 Kota Malang, sekolah negeri yang menjalankan kurikulum nasional. Sekolah ini tergolong sekolah yang masih dalam proses peningkatan mutu pendidikan. Banyak faktor yang menentukan berhasil tidaknya suatu pembelajaran. Faktor-faktor tersebut antara lain media pembelajaran yang digunakan yang masih menggunakan buku LKS atau buku cetak, metode yang digunakan oleh guru berupa ceramah dan sistem hafalan, kemudian kemampuan guru dalam mengelola kelas yang kurang kondusif seperti yang terlihat di kelas XII IPS J 5, partisipasi siswa dalam pembelajaran yang menganggap pembelajaran Sosiologi membosankan, potensi siswa yang sebenarnya bisa diasah namun masih kurang adanya kemauan dari siswa yang bersangkutan, serta interaksi antara siswa dengan guru pada proses pembelajaran yang tidak berjalan sebagaimana mestinya dimana ada dari beberapa siswa yang menganggap guru yang bersangkutan sebagai teman yang seumuran.

Guru dalam sebuah sistem pendidikan memiliki peran penting sebagai perantara dalam tranfer ilmu kepada peserta didik. Banyak dari para guru yang memiliki ciri khas masing-masing dalam menyampaikan bidang atau kajian ilmu yang dimiliki kepada peserta didiknya, beberapa guru yang masih menggunakan metode ceramah lebih banyak berbicara dalam kelas tanpa banyak memperhatikan keaktifan peserta didik di kelas, ada juga melalui penugasan, ataupun tanya jawab. Hal tersebut yang membuat siswa merasa bosan akan pembelajaran dikelas, banyak dari para siswa yang cuek akan mata pelajaran sosiologi dalam kelas.

Cara tersebut merupakan cara lama dimana guru memberikan materi hanya melalui ceramah di dalam kelas yang membuat siswa bosan terhadap mata pelajaran atau materi yang disampaikan oleh guru, maka dari itu sebaiknya guru mulai meninggalkan cara-cara lama tersebut dan disisi lain mulai mengembangkan proses pembelajaran atau metode pembelajaran yang memadai bagi siswa saat ini agar mencapai peningkatan dalam proses belajar mengajar, seperti metode lesson study atau LS. Dalam proses lesson study terdapat 3 tahapan yaitu perencanaan (plan), pelaksanaan (do), dan melihat kembali atau refleksi (see) Lesson Study dilakukan dengan tiga tahapan yaitu perencanaan (Plan), pelaksanaan (Do), dan melihat kembali atau refleksi (See). Ketiga tahapan tersebut dilakukan secara berulang (Siklus). Tahap perencanaan (Plan) bertujuan untuk menghasilkan rancangan pembelajaran yang diyakini mampu membelajarkan siswa secara efektif dan membangkitkan partisipasi siswa dalam pembelajaran. Tahap pelaksaan (Do) dimaksud untuk penerapan rancangan pembelajaran yang telah direncanakan. Tahap pengamatan dan refleksi (See) dimaksudkan 
untk menemukan kelebihan dan kekurangan pelaksanaan pembelajaran. Serangkaian kegiatan mulai tahap Plan sampai See dilakukan secara kolaboratif bersama guru model (Susilo, 2009:34-36).

\section{METODE PENELITIAN}

\section{Jenis Penelitian}

Penelitian tindakan kelas merupakan gabungan definisi dari tiga kata yaitu "penelitian"+"tindakan"+ "kelas". Penelitian dapat diartikan sebagai kegiatan mencermati suatu objek dengan menggunakan cara dan metodologi tertentu untuk memperoleh data ataupun informasi yang bermanfaat dalam memecahkan suatu masalah. Tindakan yaitu sesuatu gerak kegiatan yang sengaja dilakukan dalam Penelitian Tindakan Kelas berbentuk suatu rangkaian siklus kegiatan. Kelas yaitu sekelompok siswa atau peserta didik dalam waktu yang sama, menerima pelajaran yang sama pula. Siswa yang belajar tidak hanya terbatas dalam sebuah ruangan kelas saja, melainkan dapat juga ketika siswa sedang melakukan karyawisata, pratikum di laboratorium, atau belajar ditempat lain dibawah arahan guru (Suharsimi,2002).

Penelitian Tindakan Kelas (PTK) merupakan penelitian tindakan yang dilakukan oleh guru dengan tujuan untuk memperbaikimutu pelaksanaan pembelajaran di kelasnya (Suparno,2008). Penelitian Tindakan Kelas merupakan pengembangan dari penelitian tindakan. Penelitian tindakan (action research) termasuk dalam ruang lingkup penelitian terapan yang menggabungkan dengan pengetahuan, penelitian dan tindakan. Penelitian Tindakan Kelas berfokus pada proses belajar mengajar yang terjadi didalam kelas dan terjadi pada situasi yang alami (sebenarnya). Hal tersebut menunjukkan bahwa tindakan tersebut adalah suatu kegiatan yang sengaja dirancang dan direncanakan untuk dilakukan oleh peserta didik dengan tujuan tertentu yaitu untuk memperbaiki kualitas pembelajaran sehingga kegiatan yang dilakukan harus berupa suatu tindakan yang dipercaya lebih efektif, efisien, kreatif dan inovatif dari kegiatan-kegiatan sebelumnya. Dalam penelitian Tindakan Kelas terdapat misi peningkatan dan perubahan. Penelitian Tindakan Kelas bukan penelitian yang hanya sekedar penyelesaian masalah, tetapi penelitian yang dilakukan oleh seorang guru atau peneliti terhadap kinerjanya untuk melakukan peningkatan dan perubahan terhadap apa yang sudah dilakukan. PTK juga tidak semata-mata hanya menerapkan metode ilmiah dalam proses pembelajaran atau sekedar menguji hipotesis yang telah dirumuskan, tapi lebih memfokuskan perhatian pada perubahan.

Penelitian Tindakan Kelas (PTK) sangat penting bagi seorang guru karena dapat membantu mereka untuk mengembangkan keterampilan dan pengetahuan, memahami lebih baik tentang pembelajarnnya dan dapat melakukan suatu tindakan untuk meningkatkan semangat belajar peserta didiknya sehingga proses belajar mengajar didalam kelas akan mengalami perubahan dan peningkatan prestasi. Seorang guru yang telah melakukan Penelitian Tindakan Kelas, dapat dikatakan seorang guru tersebut telah menjalankan misi sebagai guru profesional, yaitu membelajarkan, melakukan pengembangan profesi berupa penulisan karya ilmiah dari hasil Penelitian Tindakan Kelas dan melakukan Ihtiar untuk peningkatan mutu proses dan hasil pembelajaran. Dapat disimpulkan bahwa dasar utama dalam pelaksanaan PTK adalah 
untuk sebuah perbaikan. Perbaikan yang dimaksud terkait dengan memiliki konteks dalam proses pembelajaran itu sendiri. Tujuan PTK ini dapat diwujudkan dengan melakukan berbagai tindakan alternatif dalam memecahkan berbagai masalah dalam pemebelajaran. Sehingga fokus yang diambil dalam penelitian tindakan kelas terletak pada tindakan-tindakan alternatif yang direncanakan oleh pendidik yang kemudian dilakukan dan selanjutnya dilakukan evaluasi.

\section{Penelitian Tindakan Kelas Kolaboratif dengan Lesson Study}

Lesson Study merupakan suatu pendekatan peningkatan kualitas pembelajaran yang dilaksanakan oleh guru secara kolaboratif, dengan langkah-langkah pokok merancang pembelajaran untuk mencapai tujuan, melaksanakan pembelajaran, mengamati pelaksanaan pembelajaran tersebut, serta melakukan refleksi untuk mendisukusikan pembelajaran yang dikaji tersebut dan menyempurkannya dan merencanakan pembelajaran berikutnya.

Salah satu produk Lesson Study adalah membantu siswa dalam meningkatkan motivasi belajar, proses keterampilan, pengetahuan, antusiasme dalam melakukan kerja sama, dan komunikasi yang baik. (Sukirman, 2007)

\section{Tahapan Lesson Study}

Secara umum, Lesson Study memiliki beberapa tahapan (Chong dkk., 2017), yaitu plan, do, dan reflection, lalu dilanjutkan dengan satu tahap lagi, yaitu supervisi klinis. Secara teknis, empat tahap tersebut dipaparkan sebagai berikut:

1. Plan (perencanaan pembelajaran)

Setelah sebelumnya menemui GP untuk melakukan identifikasi SK/KI dan KD yang akan diajarkan pada saat di sekolah, langkah awal yang dilakukan mahasiswa dalam rangkaian Lesson Study adalah merancang pembelajaran. Dalam hal ini mahasiswa menyusun perangkat pembelajaran secara kolaboratif. Perangkat yang dimaksud meliputi RPP, bahan ajar, dan media pembelajaran. Kegiatan ini dilakukan secara kolaboratif antara mahasiswa, teman sejawat, dan Dosen Pembimbing. Kolaborasi dapat dilakukan dengan cara mempresentasikan secara bergantian perangkat pembelajaran yang disusun salah seorang mahasiswa untuk mendapat masukan dari mahasiswa yang lain dan DP. Kegiatan ini dilakukan secara kolaboratif antara mahasiswa, teman sejawat, Dosen Pembimbing, dan Guru Pamong.

2. Do (pelaksanaan dan pengamatan pembelajaran)

Langkah ini dimaksudkan untuk melaksanakan pembelajaran di kelas berdasarkan perangkat pembelajaran yang telah disiapkan sebelumnya. Kegiatan ini dilakukan oleh salah seorang dari mahasiswa yang terlibat dalam kegiatan perencanaan pembelajaran. Bersamaan dengan pelaksanaan pembelajaran, dilakukan pengamatan terhadap pelaksanaan pembelajaran tersebut. Pada saat pengamatan, kegiatan ini dilakukan oleh mahasiswa dalam satu rombel. Mahasiswa yang lain masih berperan sebagai supervisor saja, namun diharapkan dapat berperan aktif juga sebagai observer. Tiap rombel minimal dilakukan $2 \mathrm{x}$ Lesson Study dan terintegrasi dengan praktik peer-teaching. Penentuan siapa mahasiswa yang pembelajarannya akan diamati (sebagai 'guru model') dan siapa mahasiswa yang berperan sebagai observer dilakukan oleh DP. 
3. Reflection (refleksi pembelajaran)

Setelah melaksanakan pembelajaran dan pengamatan, seluruh pihak yang terlibat dalam aktivitas pengamatan melakukan refleksi untuk mendiskusikan pembelajaran yang dikaji dan menyempurkannya, serta merencanakan pembelajaran berikutnya. Dalam tahap refleksi ini, pembahasan tidak dimaksudkan untuk mengomentari aktivitas 'guru model' ketika melaksanakan pembelajaran, melainkan lebih diarahkan pada hasil pengamatan terhadap perilaku siswa selama proses pembelajaran di kelas. Dengan demikian tidak ada komentar terhadap perilaku guru ketika mengajar. Diharapkan, berdasarkan paparan hasil pengamatan terhadap perilaku siswa tersebut, 'guru model' akan dapat merefleksi dirinya sendiri. Diharapkan 'guru model' dan setiap observer dapat menemukan good practices dari praktik Lesson Study yang diikutinya. Pada tahap ini apabila sejak semula DP dan GP menempatkan diri sebagai observer, maka mereka juga berperan sebagai reflektor. Namun apabila sejak semula DP dan GP berperan sebagai supervisor, maka pada tahap ini mereka tetap mengikuti proses refleksi dengan menempatkan diri sebagai orang luar.

\section{Supervisi Klinis}

Tahap ini dilakukan setelah seluruh rangkaian praktik Lesson Study selesai dilakukan. Pada saat ini sepenuhnya DP dan GP berperan sebagai supervisor, yaitu memberi saran dan masukan secara langsung kepada mahasiswa yang berperan sebagai 'guru model'. Diharapkan saran dan masukan tersebut dapat diakomodasi juga oleh mahasiswa lain dalam satu kelompok.

\section{Teknik Pengumpulan Data}

Teknik pengumpulan data yang digunakan dalam penelitian tindakan kelas di SMAN 9 Malang adalah dengan menggunakan metode observasi langsung dimana dengan metode ini kami secara langsung mengamati, mencatat, dan mendokumentasikan segala macam subjek maupun objek tertentu, baik dikelas maupun disekolah yang nantinya akan dipilih dan dipilah mana kah yang dapat dijadikan sebagai data utama dan/atau data pendukung. Kami juga menggunakan kamera sebagai alat dokumentasi agar gambar yang bisa ditampilkan dapat dijadikan sebuah data dukungan sekaligus sebagai bukti bahwa kami telah melakukan penelitian tindakan kelas di SMAN 9 Malang. Selain itu kami juga menggunakan teknik wawancara secara langsung kepada guru pamong, mahasiswa PPL, dan murid-murid peserta LS untuk menggali data tentang bagaimana PTK itu dilaksanakan, apa motif utama dari dilaksanakannya PTK, bagaimana hasil yang diperoleh setelah dilaksanakannya PTK, dan bagaimana respon murid-murid dengan diadakannya PTK.

\section{Validitas}

Penelitian ini menggunakan 3 tipe validitas, yaitu;

1. Validitas Administrasi Akademik, tipe validitas ini berbentuk model RPP.

2. Validitas Konsep, validitas ini menghasilkan PTK Model Jigsaw

3. Validitas Aktivitas Pembelajaran, validasi ini menghasilkan imple-mentasi lesson study pada pembelajaran sosiologi kelas XII J 5 IPS melalui empat tahap yaitu;

a. tahap pengkajian/orientasi akademik (Akadekic oriended),

b. tahap perencanaan (plan),

c. tahap pelaksanaan dan observasi (do) 
dan

d. tahap tindak lanjut (refleksi). atau refleksi diri yang didasarkan pada hasil penelitian. Prosedur dalam penelitian ini (gambar 1) menggunakan model siklus dengan 4 tahapan yaitu planning, acting, observing dan reflecting menurut Lewins dan McNiff.

\section{Analisis Data}

Penelitian tindakan merupakan metode yang mengembangkan dan menyempurnakan ilmu dalam mengatasi masalah melalui tindakan

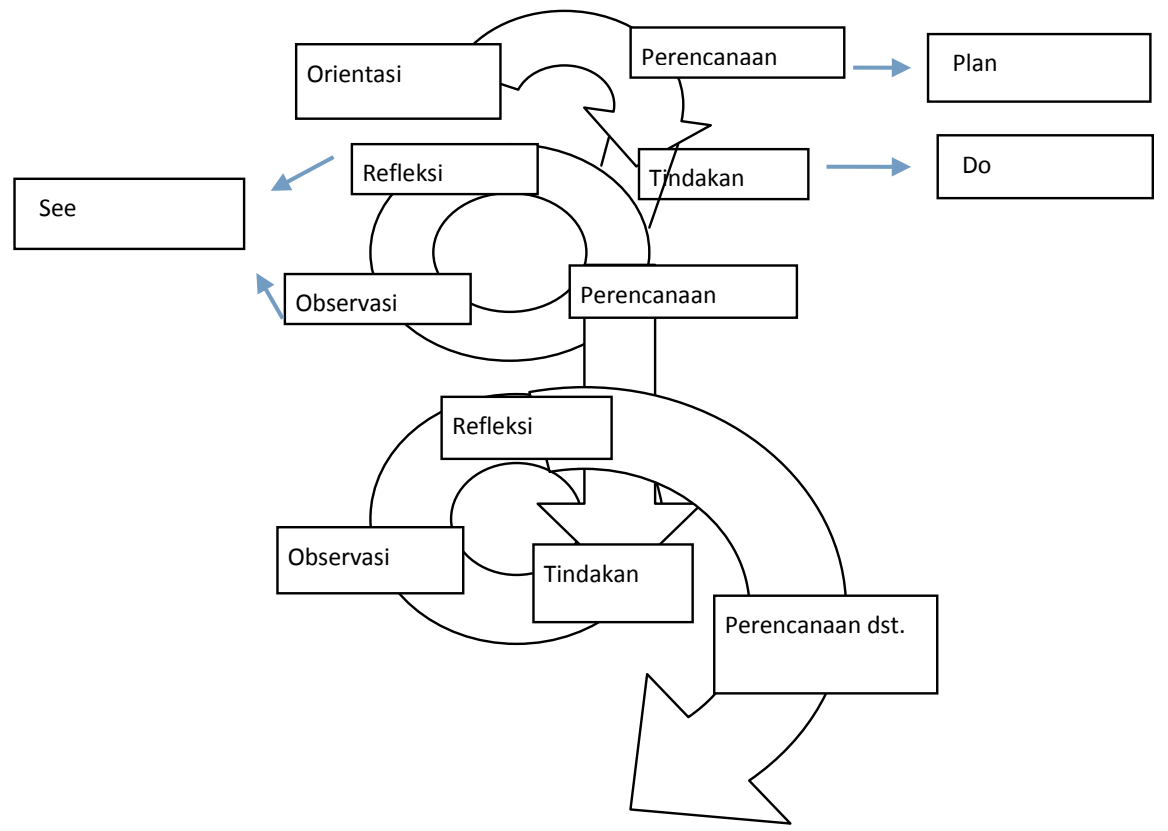

Gambar 1. Prosedur penelitian

1. Orientasi adalah menemukan apa yang mejadi masalah atau penghambat aktifitas belajar mengajar. Di saat pembelajaran berlangsung, yang menjadi masalah atau penghambat aktifitas belajar mengajar adalah banyaknya siswa yang ramai, tidak berkonsentrasi pada pelajaran, dan bermain HP/gawai masing-masing.

2. Perencanaan adalah upaya untuk mempersiapkan kegiatan dan tindakan yang akan diterapkan unutk memperbaiki kinerja dalam belajar mengajar. Upaya ini sudah dilaksanakan dengan cara menyusun RPP yang akan dilaksanakan dikelas, membuat media pembelajaran yang menarik, dan persiapan materi pembelajaran oleh guru model yang akan tampil dikelas.

3. Pelakasanaan tindakan adalah aktivitas guru dalam menerapkan rencana yang telah disepakati bersama oleh peneliti. Pelaksanaannya adalah dengan menggunakan metode pembelajaran jigsaw dan dilanjutkan metode pembelajaran snowball dengan menggunakan media pembelajaran poster yang berisi gambar keadaan sosial, dengan tujuan agar siswa dapat mengkategorikan bentuk-bentuk ketimpangan sosial yang terjadi di dalam masyarakat.

4. Observasi adalah kegiatan mengumpulkan informasi yang berkaitan dengan rencana, proses, hasil tindakan yang diperoleh sebagai bahan dalam melakukan refleksi dan perbaikan untuk siklus selanjutnya. Peneliti dan guru model secara bersamasama telah menerapkan PTK dan sebagai observer dikelas dengan menjalankan 
tugas masing-masing yaitu pengajaran, observasi, pengamatan, dan refleksi.

5. Refleksi adalah perenungan kembali dan koreksi terhadap kemungkinan terjadinya kekurangan dan kekeliruan atau penyimpangan dalam tindakan yang telah dilaksanakan. Refleksi dilaksanakan setelah semua kegiatan pembelajaran di suatu dikelas sudah usai. Refleksi dilaksanakan oleh guru model, observer, dan guru pamong guna mengevaluasi pembelajaran yang sudah dilaksanakan dan melakukan perbaikan di siklus berikutnya.

\section{HASIL PENELITIAN DAN PEMBAHASAN}

\section{Penerapan model pembelajaran Jigsaw} terhadap keaktifan belajar siswa kelas

\section{J 5 SMA Negeri 9 Malang}

Kelas XII J 5 di SMA Negeri 9 Malang yang telah kami observasi keadaan di dalam kelas dari sebelum berlangsungnya pembelajaran dan saat pembelajaran berlangsung dimulai oleh guru model, memang dapat mudah ditebak bagaimana kondisi yang terjadi pada hari pertama observasi. Umumnya kelas terbentuk tenang maupun ramai apabila guru dapat mengkondisikan kelas secara disiplin agar siswa dapat mematuhi aturan yang telah disepakati bersama saat melakukan pengenalan terlebih dahulu. Pengenalan tidak serta merta hanya dilakukan oleh guru melainkan siswa pun harus ikut memperkenalkan diri mereka sendiri. Begitu juga dengan guru model yang mengajar kelas XII J 5 di SMA Negeri 9 Malang.

Suatu hal yang dimulai dari kesepakatan, mungkin akan berjalan dengan baik agar dapat menciptakan proses belajar mengajar yang menyenangkan. Menyenangkan diantaranya dapat membuat siswa dan guru nyaman, membuat siswa dapat berinteraksi di kelas baik dengan guru maupun dengan teman sejawat, saling bertukar pendapat sehingga dapat membuat kelas tidak menjadi membosankan. Bosan tidak hanya terarah pada metode guru mengajar menggunakan ceramah, tetapi kebosanan akan tampak jika siswa kurang antusias dengan pembelajaran yang diajarkan, guru menghiraukan siswa yang sedang ramai, guru hanya menyampaikan materi tanpa mengajak siswa untuk ikut serta saat proses belajar mengajar.

Mengenai ulasan yang dijelaskan diatas, kegiatan siswa memang harus dipantau terlebih oleh guru. Karena saat ini guru tidak hanya sebagai pengajar, tetapi siswa pun juga harus ikut dan andil dalam proses pembelajaran yang diantaranya sama-sama dapat menjadi pembelajaran secara bersamasama. Siswa terlibat aktif di dalam proses pembelajaran, guru mengarahkan siswanya supaya ikut belajar dalam kegiatan yang sedang berlangsung.

Kondisi yang terjadi di kelas XII J 5 SMA Negeri 9 Malang setelah kami pantau semaksimal mungkin dari observasi pertama sampai kedua dapat dikatakan tidak ada perubahan yang terjadi. Kegiatan siswa di ruang kelas cenderung sibuk dengan aktivitasnya sendiri. Tidak sedikit dari mereka yang menggunakan smartphone di dalam kelas. Kegiatan yang terjadi diantaranya seorang siswa laki-laki bermain game online pada aktivitas pembelajaran dimulai. Ada di antara siswa perempuan masih mencuri kesempatan untuk membalas pesan social media yang telah kami amati pada observasi kedua.

Observasi memang telah mendapatkan kesepakatan antara guru model dengan guru 
mata pelajaran sosiologi. Usulan kelompok untuk mengetahui bagaimana perkembangan siswamelaluimediapembelajaran, makakami menggunakan media tabel pengkategorian dengan merumuskan masalah-masalah sosial sesuai tempatnya yang terbuat dari karton berukuran persegi kecil dengan menggunakan model pembelajaran jigsaw.

Sebelum menggunakan media tersebut, guru model menjelaskan terlebih dahulu materi tentang ketimpangan social sebagai dampak perubahan sosial di tengah globalisasi. Setelah itu, siswa di bagi kelompok-kelompok asli berjumlah 7-8 siswa, satu orang ditunjuk untuk menjelaskan materi terdiri dari 4 sub bab yaitu: Diskriminasi Sosial, Kecemburuan Sosial, Konflik Sosial, dan Monopoli. Anggota kelompok ahli berkumpul dengan anggota kelompok lain yang memiliki materi yang sama(Kelompok ahli). Kelompok ahli saling bekerjasama dan berdiskusi mendalami materi yang sudah didiskusikan pada saat berada di kelompok ahli. Setelah semua kelompok selesai menjelaskan, masingmasing kelompok menulis pertanyaan dalam selembar kertas. Guru memastikan tidak ada pertanyaan yang sama dengan kelompok lain. Kertas dilempar kepada kelompok lain secara bergantian. Kelompok harus menjawab pertanyaan tersebut. Selanjutnya, penerapan model pembelajaran sederhana berbentuk gambar dan karton untuk mengelompokan dan menempatkan gambar pada 4 kategori: Diskriminasi Sosial, Kecemburuan Sosial, Konflik Sosial, dan Monopoli.

Setelah pemberian materi oleh guru model dan penerapan Jigsaw ternyata siswa masih merasa bingung dari penjelasan yang telah didapatkan dari guru model. Memang guru menjalaskan tetapi tidak menggunakan media seperti power point untuk mejelaskan. Sehingga saat penerapan media pembelajaran picture siswa binggung dan salah saat menempatkan gambar yang ada di karton ini menandakan bahwa siswa belum paham materi.

Guru model kurang menguasai materi dan tidak dapat mengkondisikan kelas. Siswa di dalam kelas yang masih bermain game di handphone, mereka tidak merasa canggung karena guru model tidak bersikap professional seperti teman sendiri. Suatu kebiasaan buruk yang diabaikan dapat memperburuk keadaan. Karena hal tersebut dilakukan berulang ulang. Kebiasaan baik dapat dibentuk jika guru dan siswa sejak awal memiliki kesepakatan yang telah disepakati secara bersama dan dapat dipatuhi. Maka peran guru mendidik siswa tidak hanya melalui pelajaran akademik, melainkan pembelajaran karakter ikut diterapkan.

\section{Hasil penerapan model pembelajaran} Jigsaw terhadap keaktifan belajar siswa kelas XII J 5 IPS SMA Negeri 9 Malang Pada kelas XII IPS J5 terdapat 34 jumlah siswa, berdasarkan pengamatan yang dilakukan kelompok kami, kondisi siswa didalam kelas cukup aktif akan tetapi lebih banyak siswa yang ramai sendiri dan bergurau. Banyak siswa yang bermain hp, bergurau dengan teman bahkan ada juga yang tidur. Menurut pandangan kelompok kami hal yang menyebabkan kondisi siswa seperti itu adalah kurangnya pengondisian yang dilakukan oleh guru sehingga siswa tidak terkontrol. Hal lain yang mungkin menjadi penyebab kondisi kelas yang ramai adalah guru tidak menggunakan metode pembelajaran yang tepat sehingga siswa tidak berantusias mengikuti pelajaran. 
Tindakan pada siklus 1 ini terdapat satu kali tindakan. Tindakan ini dilakukan pada tanggal 6 Oktober 2017. Pada tanggal ini, kelompok kami datang ke SMAN 9 Malang untuk bertemu dengan salah satu guru model yang akan kita ajak untuk melakukan pengajaran kolaboratif dikelas XII IPS. Kami menawarkan model pembelajaran kooperatif menggunakan model jigsaw, dan untuk menambah tingkat minat dan keaktifan siswa dalam belajar, kami mengusulkan penggunaan media picture and picture dimana strategi ini diharapkan dapat menumbuhkan minat belajar siswa sekaligus meningkatkan tingkat keaktifan siswa dalam belajar Sosiologi kelas XII.

Setelah model dan media pembelajaran sudah disepakati bersama, pada tanggal Oktober 2017, kami melaksanakan Penelitian Tindakan Kelas (PTK) berkolaborasi dengan Lesson Study menggunakan guru model merupakan mahasiswa KPL. Pembelajaran yang diajarkan berdurasi $2 \times 45$ menit. Materi yang diajarkan adalah tentang kesenjangan sosial, dimana dalam bab ini terdapat beberapa sub bab diantaranya adalah: diskriminasi, keemburuan sosial, monopoli, konflik sosial.

Proses pembelajaran dikelas dilaksanakan sesuai dengan rancangan pembelajaran yang sudah dibuat, yaitu pertama-tama guru model melaksanakan kegiatan pendahuluan antara lain; membuka kegiatan pembelajaran dengan doa, presensi, memberi penjelasan secara garis besar tentang materi yang akan disampaikan, memberikan umpan kepada siswa agar siswa mengingat kembali pelajaran tentang ketimpangan sosial yang sebelumnya, dan menjelaskan tujuan pembelajaran pada hari itu. Lalu untuk kegiatan inti dilaksanakan selama 60 menit yang pertama yakni guru menjelaskan materi mengenai ketimpangan sosial mulai dari diskriminasi sosial, kecemburuan sosial, monopoli dan konflik sosial. Setelah guru menjelaskan, guru membagi menjadi 4 kelompok.

Masing masingkelompokasli(berdasarkan nomor urut) diberikan materi yang berbeda. Kemudian anggota kelompok ahli berkumpul dengan anggota lain yang memiliki materi yang sama. Setelah berdiskusi setiap anggota kembali ke kelompok aslinya masing-masing dan menjelaskan materi yang telah diperoleh. Dari penggunaan metode tersebut diharapkan setiap siswa dapat mengerti dan memahami materi yang diberikan oleh guru.

Hasil observasi keaktifan belajar siswa dalam penggunaan model pembelajaran kooperatif tipe jigsaw adalah siswa menjadi lebih aktif dan reaktif dalam belajar mata pelajaran sosiologi. Hal ini dibuktikan dengan dari jumlah keseluruhan siswa sebanyak 38 murid, terdapat sejumlah 18 siswa yang aktif dalam menjawab pertanyaan dan berargumentasi mengenai materi pembelajaran. Dilihat dari data yang disebutkan diatas, maka dapat disimpulkan bahwa siswa kelas XII menjadi lebih aktif dalam mempelajari mata pelajaran Sosiologi.

Lalu untuk tingkat kepedulian siswa dalam mengikuti mata pelajaran Sosiologi adalah masih terdapat siswa yang bermain Handphone sendiri, ngobrol dengan teman sebangku, dan tidur dikelas. Hal ini diakibatkan dari guru model yang kurang bisa mengkondisikan siswa dikelas secara efektif, sehingga keberlangsungan mata pelajaran Sosiologi dinilai masih belum efektif sepenuhnya. Solusinya, guru harus lebih bisa mengkondisikan kelas dengan cara-cara seperti memberikan perhatian khusus kepada 
siswa yang ramai, dan menjaga kewibawaan seorang guru di mata siswa.

Siklus Kedua dilaksanakan dengan model Jigasaw. Materi yang dipaparkan yaitu Pada diagram diatas dapat diketahui bahwa pencapaian kegiatan atau perilaku siswa yang diamati pada siklus II pertemuan 2 ini terdapat peningkatan keaktifan jika dibandingkan dengan pencapaian kegiatan pada pertemuan 1. Sesuai dengan tabel diatas berikut adalah penjelasan dari pencapain kegiatan setiap indikator pada observasi keaktifan belajar siswa pada siklus II pertemuan 2. Memperhatikan penjelasan guru atau teman serta mencatat hasil diskusi dari 34 siswa yang hadir ada 12 siswa yang melakukannya, Membaca buku atau mencari referensi lain di internet yang berkaitan dengan materi yang ditugaskan oleh guru serta bertanya saat proses pembelajaran berjumlah 20 siswa. Membahas materi yang ditugaskan guru bersama anggota kelompok lain yang memiliki tugas yang sama (disebut kelompok ahli) dan Menjelaskan kepada anggota kelompok mengenai subbab materi yang dikuasai (disebut kelompok asal) dari 34 siswa yang hadir ada 27 siswa yang melakukannya.

Dalam proses pelaksanaan pembelajaran Siklus 2 Siswa kelas xii j 5 berperan aktif dalam kegiatan diskusi, memberikan gagasan, menyampaikan dengan baik saat menjelaskan, tetapi cenderung tidak bisa menghargai gagasan orang lain.

Berdasarkan pembahasan yang diuraikan, telah menunjukkan bahwa implementasi Strategi Pembelajaran Kooperatif Teknik Jigsaw dapat meningkatkan Keaktifan Belajar Sosiologi Kelas XII J 5 SMA Negeri 9 Malang tahun ajaran 2017/2018. Hal tersebut sesuai dengan teori yang dinyatakan oleh
(Yatim, 2009),bahwa dengan implementasi Strategi Pembelajaran Kooperatif maka siswa dapat memperoleh keterampilan diantaranya berbagi tugas dan mengambil bagian dalam tugas, mengajukan pertanyaan, mendengar dengan aktif, dan bekerja sama. Selain itu, sesuai dengan yang dinyatakan oleh (Anita, 2008) bahwa dengan penerapan Teknik Jigsaw, siswa melakukan kegiatan membaca, menulis, mendengarkan, dan berbicara.

Dengan penggunaan berbagai teknik dalam strategi pembelajaran kooperatif, diantaranya teknik pembelajaran Jigsaw, siswa dapat memusatkan perhatian kepada pembelajaran, sehingga pemahaman siswa terhadap materi pembelajaran dapat ditingkatkan, juga dapat membelajarkan keterampilan sosial. Hal tersebut tampak dari adanya kerja sama antar siswa dalam teknik pembelajaran Jigsaw sebagai upaya untuk memahami konsep dalam materi pelajaran. Dengan adanya kerjasama tersebut, akan melatih keterampilan siswa dalam hal bersosialisasi dengan teman sebaya dan juga akan berpengaruh terhadap meningkatnya keaktifan belajar siswa.

\section{PEMBAHASAN}

Hasil keberhasilan berdasarkan Indikator keaktifan dalam metode pembelajaran jigsaw di kelas XII IPS J 5 SMA Negeri 9 Malang

Menurut Paul D. Derich siswa dapat dikatan aktif apabila menunjukkan 9 indikator keaktifan diantaranya aktif dalam visual, oral (lisan), mendengarkan, menulis, menggambar, melakukan percobaan (metrik), berpikir (mental), dan emosional. Berdasarkan observasi kelompok kami terhadap siswa kelas XII IPS J 5 SMA 
Negeri 9 Malang dalam materi kesenjangan sosial, siswa menunjukkan setidaknya 7 tanda keaktifan yang disebutkan oleh Paul D. Derich, diantaranya dalam kegiatan visual, dimana sebagian siswa mau memperhatikan dan membaca materi tentang kesenjangan sosial yang tengah disampaikan oleh guru model, sedangkan siswa yang lain masih ada yang bermain hp atau tidur. Dalam kegiatan oral hampir semua siswa aktif dalam berbicara mengenai materi yang disampaikan dalam kelompoknya dan menjelaskan materi yang telah dipelajari oleh kelompok asal ke dalam kelompok ahli dimana siswa mengemukakan pendapatnya sendiri berdasarkan hasil diskusi dengan kelompok asal masing-masing. Disisi lain dalam indikator mendengarkan terlihat sebagian siswa antusias dalam mendengarkan materi yang disampaikan baik oleh guru model ataupun teman yang berasal dari kelompok ahli, walaupun masih ada diantaranya yang bermain hp atau asik sendiri. Hal yang sama juga terlihat dalam indikator menulis, siswa aktif menulis laporan tentang apa yang didapatkannya dalam diskuis baik dengan kelompok asal atau dengan kelompok ahli dan masih ada dari beberapa siswa yang masih bermain hp dan tidur, sebaliknya dalam kegiatan menggambar tidak terlihat siswa aktif dalam indikator tersebut karena guru model tidak memerintahkan siswa untuk menggambar materi yang tengah dijelaskan.

Dalam kegiatan metrik keaktifan siswa semakin besar, indikator metrik ini terlihat saat siswa dari kelompok asal melakukan percobaan atau memilih gambar untuk dicocokan dengan kolom-kolom kesenjangan sosial (picture and picture), walaupun masih banyak jawaban yang salah, namun sudah terlihat inkator keaktifan dari siswa meningkat drastis karena hampir semua siswa ikut aktif dalam mencocokan dan memberi masukan teman satu kelompok dalam memilih gambar yang cocok. Hal serupa juga terlihat dalam kegiatan mental atau berpikir, karena diakhir kegiatan siswa mencocokan gambar dengan kolom-kolom materi kesenjangan sosial siswa juga menjelaskan alasannya mengapa dia memilih menempelkan gambar dalam salah satu kolom, terlihat siswa antusias dalam melakukan analisis dan pemecahan masalah mengenai materi yang tengah disampaikan. Dilihat dalam kegiatan emosional siswa juga terlihat senang dengan mata pelajaran sosiologi menggunakan lesson study dengan metode jigsaw karena selain menyenangkan juga membuat siswa lebih aktif dalam memecahkan suatu persoalan yang disampaikan oleh guru model.

Aktivitas pembelajaran dalam pengamatan kelompok kami bisa dikatakan aktif karena banyak dari siswa yang sudah menunjukkan respon terhadap 7 dari 8 indikator yang sudah dijelaskan. Kekurangan yang kami temui dalam indikator keaktifan ini adalah ada sebagian siswa yang masih merasa bosan dengan materi yang telah disampaikan oleh guru model ataupun kelompok ahli, banyak diantara mereka yang masih asik bermain hp, tidur, ataupun bermain sendiri hal ini disebabkan karena kurang sigapnya guru model dalam mengatur kelas dan penggunaan jam istirahat sekolah untuk diteruskan dalam pembelajaran yang membuat siswa merasa bosan dan tidak memperhatikan materi yang tengah dibahas.

\section{KESIMPULAN}

Pada penelitian ini kami berusaha untuk 
mengetahui bagaimana penerapan model pembelajaran jigsaw dapat meningkatkan minat belajar siswa, dan untuk mengetahui apakah model pembelajaran seperti ini bisa efektif meningkatkan minat belajar siswa. Pada penerapan pembelajaran model jigsaw, siswa dikelompokkan dengan mekanisme tukar menukar kelompok dan anggota tiap kelompok berperan penting dalam penguasaan materi secara menyeluruh dengan disetiap kelompokkan memiliki kelompok asal dan kelompok ahli yang berbicara saling bertukar informasi.

Materi pembelajaran diberikan kepada siswa dalam bentuk teks. Setiap anggota bertanggung jawab dalam mempelajari bagian tertentu bahan yang diberikan itu. Anggota kelompok lain yang mendapat tugas topik yang bersama berkumpul dan berdiskusi tentang topik tersebut. Kelompok ini disebut kelompok ahli. Selanjutnya kelompok ahli ini kembali pada kelompok asal dan menyampaikan apa yang didapatkannya kepada teman-teman dikelompoknya. Para siswa kemudian diberi kuis atau tes secara individual oleh guru untuk melihat hasil belajar siswa. (Trianto, 2009: 73)

Berdasarkan hasil dari penelitian ini, dapat disimpulkan bahwa penggunaan model pembelajaran jigsaw sangat efektif dalam meningkatkan minat belajar siswa dikelas. Dari jenis-jenis keaktifan yang dikemukakan oleh D. Derich diatas, kami mencoba menjelaskan bagaimana tingkat keaktifan belajar siswa dikelas dengan menggunakan jenis aktifitas dalam mengukur keaktifan belajar siswa;

1. Kegiatan visual. Berdasarkan pengamatan dikelas, dengan menggunakan model pembelajaran jigsaw siswa menjadi lebih aktif secara visual. Hal ini dibuktikan pada saat media picture and picture digunakan secara tidak langsung siswa memperhatikan gambar yang dipasang dikelas, dan siswa mengkategorikan gambar sesuai kategori ketimpangan sosial yang ada (materi).

2. Kegiatan lisan. Berdasarkan pengamatan dikelas, dengan menggunakan model pembelajaran jigsaw siswa menjadi lebih aktif secara lisan. Hal ini dibuktikan pada saat satu siswa dari setiap kelompok yang ditunjuk untuk menjadi kelompok ahli. Dari sini siswa dituntut untuk aktif berbicara/menjelaskan tiap kategori dari ketimpangan sosial (materi) yang sudah diajarkan untuk mereka jelaskan kembali ke kelompok-kelompok.

3. Kegiatan mendengarkan. Berdasarkan pengamatan dikelas, dengan menggunakan model pembelajaran jigsaw siswa menjadi lebih aktif dalam hal kegiatan mendengarkan. Hal ini dibuktikan pada saat kelompok ahli menjelaskan materi yang ada, setiap siswa dari masingmasing kelompok diharuskan untuk mendengarkan penjelasan dari anggota kelompok ahli.

4. Kegiatan menulis. Berdasarkan pengamatan dikelas, dengan menggunakan model pembelajaran jigsaw siswa menjadi lebih aktif dalam hal menulis. Hal ini dibuktikan pada saat guru model menyampaikan materi, siswa juga diperintahkan oleh guru untuk mencatat materi-materi yang penting yang diajarkan didalam kelas.

5. Kegiatan menggambar. Berdasarkan pengamatan dikelas, dengan menggunakan model pembelajaran jigsaw siswa menjadi lebih aktif dalam hal menggambar. Hal ini dibuktikan pada saat siswa yang 
ditunjuk untuk maju kedepan kelas dan menggambarkan peta konsep beserta penjabarannya dari materi ketimpangan sosial.

6. Kegiatan metrik. Berdasarkan pengamatan dikelas, dengan menggunakan model pembelajaran jigsaw siswa menjadi lebih aktif dalam hal kegiatan metrik. Hal ini dibuktikan pada saat guru model memerintahkan siswa untuk membuat/ mencoba membuat model pembelajaran dari materi ketimpangan sosial berdasarkan konstruksi pemikiran mereka masing-masing.

7. Kegiatan mental. Berdasarkan pengamatan dikelas, dengan menggunakan model pembelajaran jigsaw siswa menjadi lebih aktif dalam hal mental. Hal ini dibuktikan pada saat dibentuk kelompok, setiap siswa diharapkan mampu untuk berpikir, mencari masalah riil untuk dihubungkan dengan kategori-kategori ketimpangan sosial, dan menganalisis mengapa permasalahan tersebut dapat terjadi.

8. Kegiatan emosional. Berdasarkan pengamatan dikelas, dengan menggunakan model pembelajaran jigsaw siswa menjadi lebih aktif dalam hal emosional. Hal ini dibuktikan pada saat pembelajaran berlangsung, emosi siswa sangatlah bervariatif. Mulai dari senang, antusias, ingin tahu, puas, ataupun kecewa.

Hasil observasi keaktifan belajar siswa dalam penggunaan model pembelajaran kooperatif tipe jigsaw adalah siswa menjadi lebih aktif dan reaktif dalam belajar mata pelajaran sosiologi. Hal ini dibuktikan dengan dari jumlah keseluruhan siswa sebanyak 38 murid, terdapat sejumlah 18 siswa yang aktif dalam menjawab pertanyaan dan berargumentasi mengenai materi pembelajaran. Dilihat dari data yang disebutkan diatas, maka dapat disimpulkan bahwa siswa kelas XII menjadi lebih aktif dalam mempelajari mata pelajaran Sosiologi.

Lalu untuk tingkat kepedulian siswa dalam mengikuti mata pelajaran Sosiologi adalah masih terdapat siswa yang bermain Handphone sendiri, ngobrol dengan teman sebangku, dan tidur dikelas. Hal ini diakibatkan dari guru model yang kurang bisa mengkondisikan siswa dikelas secara efektif, sehingga keberlangsungan mata pelajaran Sosiologi dinilai masih belum efektif sepenuhnya. Solusinya, guru harus lebih bisa mengkondisikan kelas dengan cara-cara seperti memberikan perhatian khusus kepada siswa yang ramai, dan menjaga kewibawaan seorang guru di mata siswa.

Siklus Kedua dilaksanakan dengan model Jigsaw. Materi yang dipaparkan yaitu, pada diagram diatas dapat diketahui bahwa pencapaian kegiatan atau perilaku siswa yang diamati pada siklus II pertemuan ke-2 ini terdapat peningkatan keaktifan jika dibandingkan dengan pencapaian kegiatan pada pertemuan ke-1.

Dalam proses pelaksanaan pembelajaran Siklus 2 Siswa kelas xii J 5 berperan aktif dalam kegiatan diskusi, memeberikan gagasan, menyampaikan dengan baik saat menjelaskan, tetapi cenderung tidak bisa menghargai gagasan orang lain.

Berdasarkan pembahasan yang diuraikan, telah menunjukkan bahwa implementasi Strategi Pembelajaran Kooperatif Teknik Jigsaw dapat meningkatkan Keaktifan Belajar Sosiologi Kelas XII J 5 SMANegeri 9 Malang tahun ajaran 2017/2018. Dengan penggunaan berbagai teknik dalam strategi pembelajaran kooperatif, diantaranya teknik pembelajaran Jigsaw, siswa dapat memusatkan perhatian 
kepada pembelajaran, sehingga pemahaman siswa terhadap materi pembelajaran dapat ditingkatkan, juga dapat membelajarkan keterampilan sosial. Hal tersebut tampak dari adanya kerja sama antar siswa dalam teknik pembelajaran Jigsaw sebagai upaya untuk memahami konsep dalam materi pelajaran. Dengan adanya kerjasama tersebut, akan melatih keterampilan siswa dalam hal bersosialisasi dengan teman sebaya dan juga akan berpengaruh terhadap meningkatnya keaktifan belajar siswa.

\section{DAFTAR RUJUKAN}

Anita, L. (2008). Cooperative Learning : Mempraktikkan Cooperative Learning di Ruang-Ruang Kelas. Jakarta: PT Grasindo.

Chong, J. S.Y., Han, S. H., Abdullah, N. A., Chong, M. S. F., Widjaja, W., \& Shahrill, M. (2017). Utilizing Lesson Study in Improving Year 12 Students' Learning and Performance in Mathematics. Mathematics Education Trends and Research. No.1 (2017) 24-31

Sukirman. (2007). Improving the quality of secondary mathematics teaching through lesson study in Yogyakarta, Indonesia. Paper presented at Third APEC-Tsukuba International Conference Innovation of Classroom Teaching and Learning through Lesson Study - Focusing on Mathematical Communication, CRICED, University of Tsukuba, Japan, December 9-14.

Yatim, R. (2009). Paradigma Baru Pembelajaran: Sebagai Referensi bagi Pendidik dalam Implementasi Pembelajaran yang Efektif dan Berkualitas. Jakarta: Kencana. 